\title{
APPLICATION OF LONG EXPANSION ROCK BOLT SUPPORT IN THE UNDERGROUND MINES OF LEGNICA-GŁOGÓW COPPER DISTRICT
}

\author{
KRZYSZTOF SKRZYPKOWSKI \\ AGH University of Science and Technology, Faculty of Mining and Geoengineering, \\ al. Mickiewicza 30, Building A4, room 10, 30-059 Kraków, Poland, \\ Tel: +48 1261721 60, Fax: +48 1261721 50, e-mail: skrzypko@agh.edu.pl
}

\section{WALDEMAR KORZENIOWSKI}

AGH University of Science and Technology, Faculty of Mining and Geoengineering, al. Mickiewicza 30, Building A4, room 228, 30-059 Kraków, Poland, Tel: +48 1261746 11, Fax: +48 1261721 50, e-mail: walkor@agh.edu.pl

\section{KRZYSZTOF ZAGÓRSKI}

AGH University of Science and Technology, Faculty of Mechanical Engineering and Robotics, al. Mickiewicza 30, Building B3, room 4, 30-059 Kraków, Poland, Tel: +48 1261730 90, e-mail: zagkrzys@agh.edu.pl

\section{PIOTR DUDEK}

AGH University of Science and Technology, Faculty of Mechanical Engineering and Robotics, al. Mickiewicza 30, Building B3, room 13, 30-059 Kraków, Poland, Tel: +48 1261730 90, e-mail: pdudek@agh.edu.pl

\footnotetext{
Abstract: In the underground mines of the Legnica-Głogów Copper District (LGOM) the main way to protect the room excavation is the use of a rock bolt support. For many years, it has proven to be an efficient security measure in excavations which met all safety standards and requirements. The article presents the consumption of the rock bolt support in the Mining Department "PolkowiceSieroszowice" in the years 2010-2015 as well as the number of bolt supports that were used to secure the excavations. In addition, it shows the percentage of bolt supports that were used to conduct rebuilding work and cover the surface of exposed roofs. One of the factors contributing to the loss of the functionality of bolt supports is corrosion whose occurrence may lead directly to a reduction in the diameter of rock bolt support parts, in particular rods, bearing plates and nuts. The phenomenon of the corrosion of the bolt support and its elements in underground mining is an extremely common phenomenon due to the favorable conditions for its development in mines, namely high temperature and humidity, as well as the presence of highly aggressive water. This involves primarily a decrease in the capacity of bolt support construction, which entails the need for its strengthening, and often the need to perform the reconstruction of the excavation.

The article presents an alternative for steel bearing plates, namely plates made using the spatial 3D printing technology. Prototype bearing plates were printed on a 3D printer Formiga P100 using the "Precymit" material. The used printing technology was SLS (Selective Laser Sintering), which is one of the most widely used technologies among all the methods of 3D printing for the short series production of the technical parts of the final product.

The article presents the stress-strain characteristic of the long expansion connected rock bolt support OB25 with a length of $3.65 \mathrm{~m}$. A rock bolt support longer than $2.6 \mathrm{~m}$ is an additional bolt support in excavations, and it is increasingly frequently used to reinforce roofs and in rebuilding the underground mines of KGHM Polish Copper S.A. In order to conduct the laboratory tests that are most suitable for the mine conditions, and yet are carried out on a laboratory test facility, the Authors used a steel cylinder with an external diameter of $102 \mathrm{~mm}$ and a length of $600 \mathrm{~mm}$, which was filled with a core of rock (dolomite) from the roofs of the mine workings.

In addition the maximum load that took over the bolt support made of rods and connected with sleeves was determined. For the initial tension, the elastic and plastic range of the maximal displacements, which were measured by the rope encoder, were determined. The statical tests of the expansion rock bolt support were carried out at the laboratory of the Department of Underground
} 
Mining in simulated mine conditions. The test facility enables the study of the long bolt rods on a geometric scale of 1:1 for the different ways of fixing. The aim of the laboratory research was to obtain the stress-strain characteristics, of the long expansion rock bolt support with a steel bearing plate and a plate printed on a 3D printer.

Key words: rebuilding of excavations, long expansion rock bolt support, ore mining, 3D printing

\section{INTRODUCTION}

The underground mines of the Legnica-Głogów Copper District (LGOM) consume an increasing number of rock bolt supports every year. The annual consumption of bolt supports in only one of the three mines of KGHM Polish Copper SA is more than 1 million units (Fig. 1). Among many factors which affect this state of affairs, one should mention: increasingly greater area of uncovered roofs (Fig. 2), increasing exploitation depth, excavations conducted in the area of goafs, the stratification construction of a roof (Fig. 3a), roof falls occurring in the roof void, weak rock layers and existing veins causing the stratification of rocks and their fall down. Interlayers tend to be washed away by water present in the roofs, which weakens roof stability, as well as numerous disturbances among which faults are particularly significant [5], [2]. First of all, one should take into account the natural hazards associated with the occurrence of the dynamic phenomena that directly destroy the structure of rocks and rock layers, cause roof watering leading to the leaching of some of the weaker strata as well as the corrosion of bolt supports. All of these factors can affect the den- sity of the net bolting in difficult roof conditions, as well as the rebuilding of preparatory, exploitation and functional excavation in facilities which have been used for a few or more than ten years and need to be reconstructed to maintain the security and functionality of an excavation site. New types of bolt support constructions are designed to absorb an increasing amount of energy and to better cooperate with the rock mass. With regard to the mechanism of taking over the loads, bolt supports can be divided into 3 types ([6]-[8], [10], [11], [13], [15], [18], [19], [24], [26]).

a) rigid bolts - with sufficient strength, undergoing damage when there is a load close to the breaking of the rod bolt, characterized by a small possibility of deformation,

b) yielding bolts - capable of moving large deformation but having low load-bearing capacity,

c) absorbing bolts - characterized by a high load carrying capacity and the ability to transfer large displacements and deformations.

In order to absorb energy, rock bolt supports should have increased tensile strength and they should maintain the nominal load in a relatively large range of displacements and deformations of the axial rod of

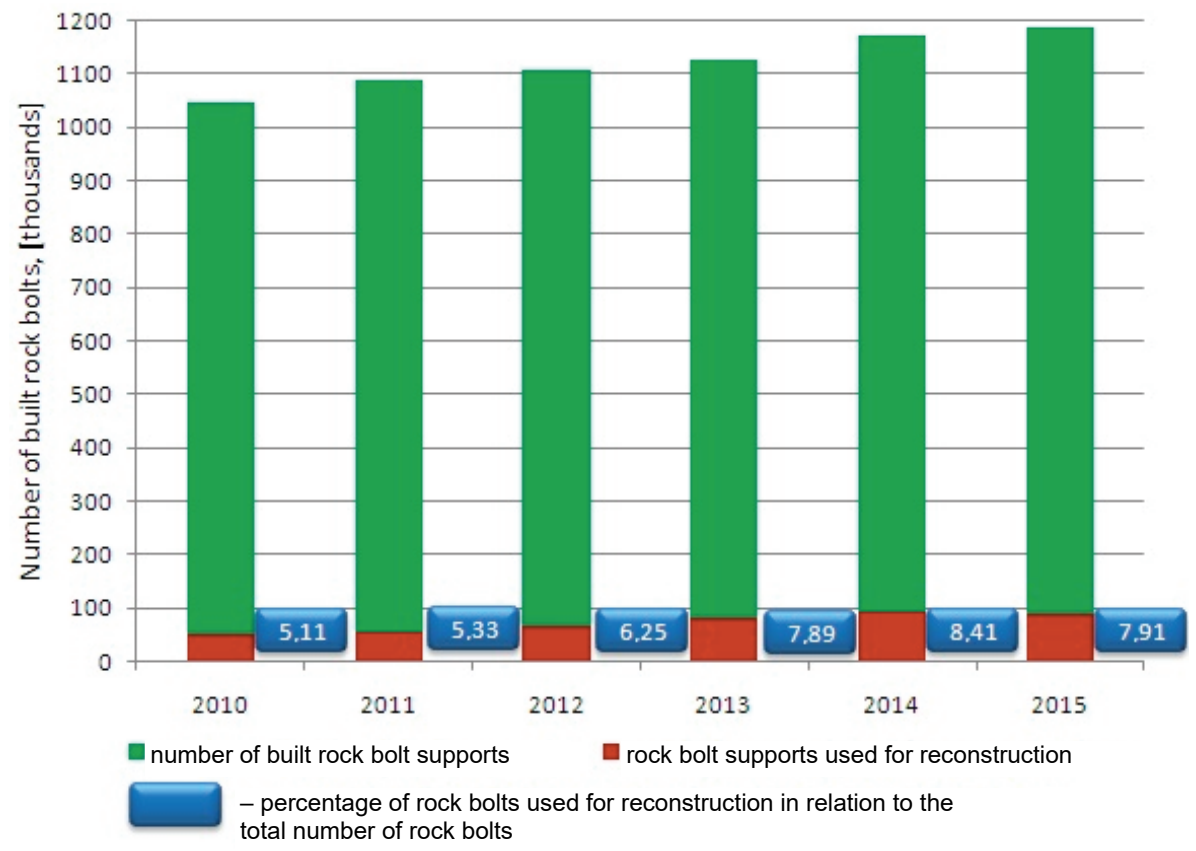

Fig. 1. Number of built rock bolt supports in the Polkowice-Sieroszowice copper mine 
the bolt. These ranges are firmly related to rock deformation capacity.

The following steps are taken when roof falls occur in an excavation site:

a) mechanical ripping of a roof and side walls (if necessary explosives are used),

b) selecting ore output or the formation of a road if a roof fall was quite high and there may be problems with the construction of a bolt support,

c) building roofs and side walls (if necessary) with a basic support selected for the reconstruction,

d) building an additional support (if necessary).

During the ripping of roofs strong rock layers should be left in the form of stairs (Fig. 3b). This allows to fasten more layers of rocks and increase the stability of the excavation. Also, it is easier to apply an additional support, e.g., a hydraulic or wooden cribs support. Rock mass does not always allow for the use of this type of ripping and reconstruction of workings. Sometimes there are situations when weaker layers of rocks occur, such as marls, and they do not retain the distribution of layers or rock fall without leaving single layers, they simply fall a few at a time. Then a void in the shape of the so-called bell is created (Fig. 3c). The reconstruction of such excavations causes numerous problems and usually is not enough to have only the basic support, in such situations an additional support and complementary elements are used.

In order to monitor a stratified roof on the crossings of excavations in room and pillar mining systems, roof stratification signaling devices are built in. These devices resemble bolt supports in their structure, however, they do not have a supporting function. They consist of a rod, head and five wooden plates attached to the roof with a control rod (Fig. 4). The wooden plates are connected by a thin rope and have drilled holes. When a signaling device is installed in the roof and the control rod begins to delaminate, the plate breaks and falls off. The wooden plate falls down after the occurrence of every $5 \mathrm{~mm}$-stratification, then it stops and hangs on a rope. As a result, it can be easily observed that something is wrong in the roof of the excavation. The number of hanging wooden plates indicates the delamination of the roof in millimeters. When the rope is broken, the wooden plates fall down. The signaling devices are $3.6 \mathrm{~m}$ long and they are

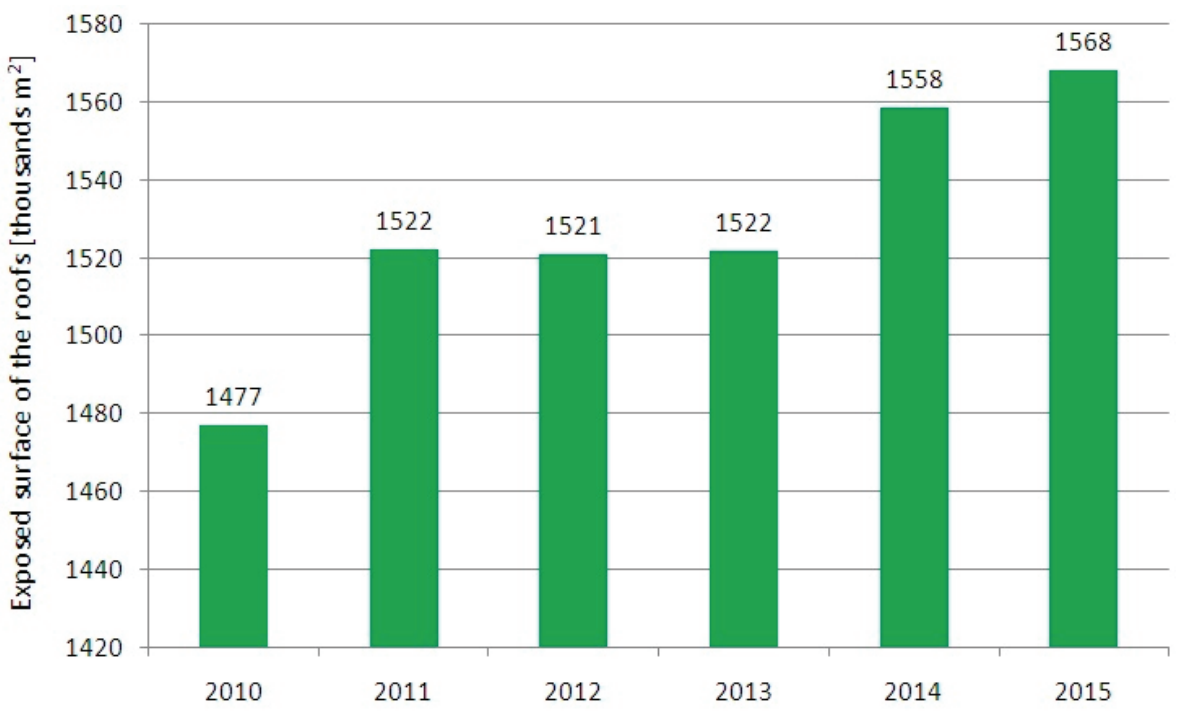

Fig. 2. Exposed surface of the roofs in individual years in the Polkowice-Sieroszowice copper mine
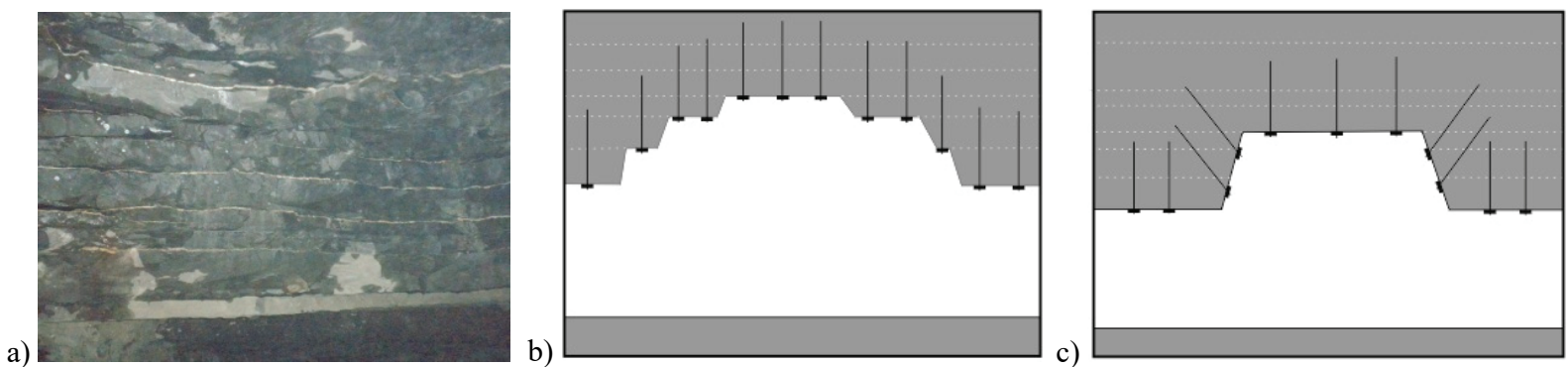

Fig. 3. Roof stratification; a) room excavation roof; b) excavation rebuild with rock layers forming stairs, c) excavation rebuilt with the occurrence of a void in the shape of a "bell" (photo by K. Skrzypkowski) 
longer than the primary bolts used in mines. If it cannot be observed that the bolts were broaching or the roof was cracked and yet a signaling device plate fell down, it is an indication that stratification occurs in layers higher than those in which the bolt support is applied. To keep all safety standards, an additional support is used or roof ripping takes place (often using blasting materials) and then the reconstruction can be conducted. Signaling devices also play an important role in the reconstruction, as they allow to react sooner and prevent accidents.

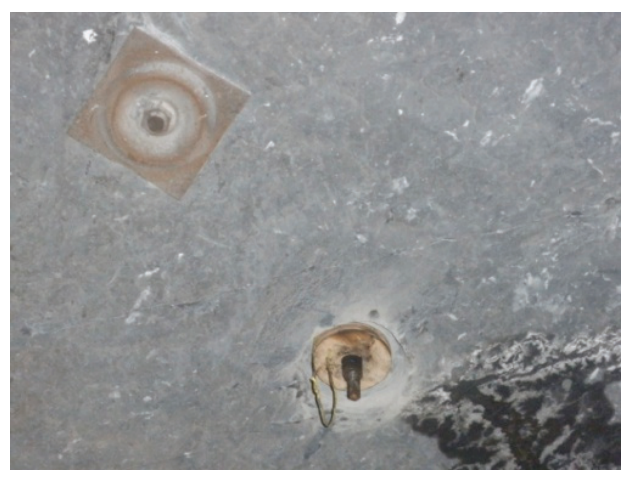

Fig. 4. Signaling device for roofs stratifications (photo by K. Skrzypkowski)

\section{CORROSION OF SUPPORT}

In the long-term excavations, rock bolt supports should maintain their strength parameters to ensure stability. One of the factors which can significantly contribute to the loss of bolt support functionality is corrosion. In the conditions existing in long-use-life excavations, due to corrosion, bearing plates made of the weakest steel grades, which carry the load of the rock mass, become the weakest element of the structural expansion and resin bolts. Corrosion reduces the dimensions of the support and is a major factor in understating its strength (Fig. 5). As a result of corrosion there are such cases when the geometry of the support is reduced, a rod bolt even breaks or the head of the bolt hole broaches in the extended bearing plate [3]. Some less common cases encompass the loss of contact between cast iron cylinder head bolts and the rock mass. This is due to the smaller amount of oxygen in the vicinity of the hole of the bolt, the higher corrosion resistance of cast iron, the fact that the jaw surface closely adheres to the rock surface and a wedge is secured with grease. The threaded head connection with a rod bolt is effectively secured by grease. The laboratory research conducted on steel bearing plates measuring $150 \times 150 \times 6 \mathrm{~mm}$ with a conical-annular profile showed that after 5 years of exposure to corrosion, breaking load was reduced from $151 \mathrm{kN}$ to $100 \mathrm{kN}$, and after 17 years it declined to $45 \mathrm{kN}$ [1]. During excavation reconstruction in hard-coal mining, long string bolt supports are frequently used devices. One of such supports was laboratory-tested in terms of corrosion rate after six years of use. In the case of string bolts with a length of $5 \mathrm{~m}$, consisting of eight strings with a diameter of $6 \mathrm{~mm}$, it was found that the diameter was reduced to $2.9 \mathrm{~mm}$, which means that the corrosion rate was $0.51 \mathrm{~mm} /$ year [25].

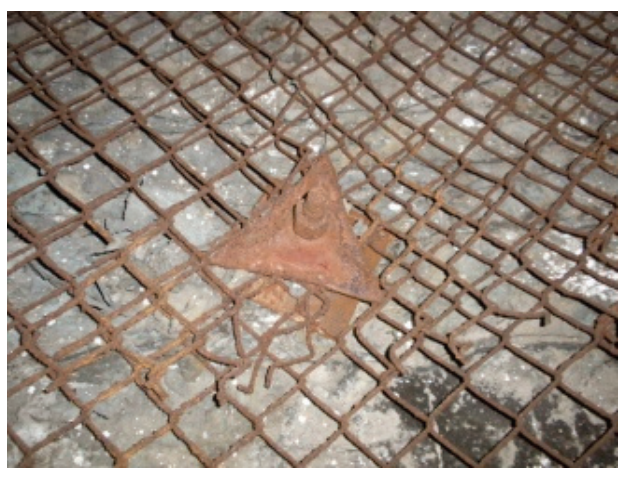

Fig. 5. Corroded parts of a rock bolt support in long-term excavation (photo by K. Skrzypkowski)

One should also take into account excavation lifetime and the aggressiveness of mine water, i.e., the fact that water with chloride concentration exceeding $1 \mathrm{~g} / \mathrm{dm}^{3}$ can aggressively affect metal structures, and higher concentrations can also affect certain types of concrete, while water with the concentration of sulfates exceeding $250 \mathrm{mg} / \mathrm{dm}^{3}$ proves aggressive to metal structures and concrete prepared based on Portland cement [20]. From the technical point of view, there are several ways of increasing the durability of bolt supports, such as: increasing the weight of bolt support elements while maintaining existing materials, the use of steel with better corrosion resistance, nitriding, carbonitriding, galvanizing and protective coatings, e.g., TEKFLEX, AGESO [7], [17], [12].

\section{SPATIAL 3D PRINTING}

$3 \mathrm{D}$ printing generally uses additive technology to make a proposed object or a physical model based on a 3D computer model [23]. The models of bearing plates were designed in the CATIA graphics program, which is specifically dedicated to engineering design work [21], creating flat documentation, simulation of the finite element method FEM and processing pro- 

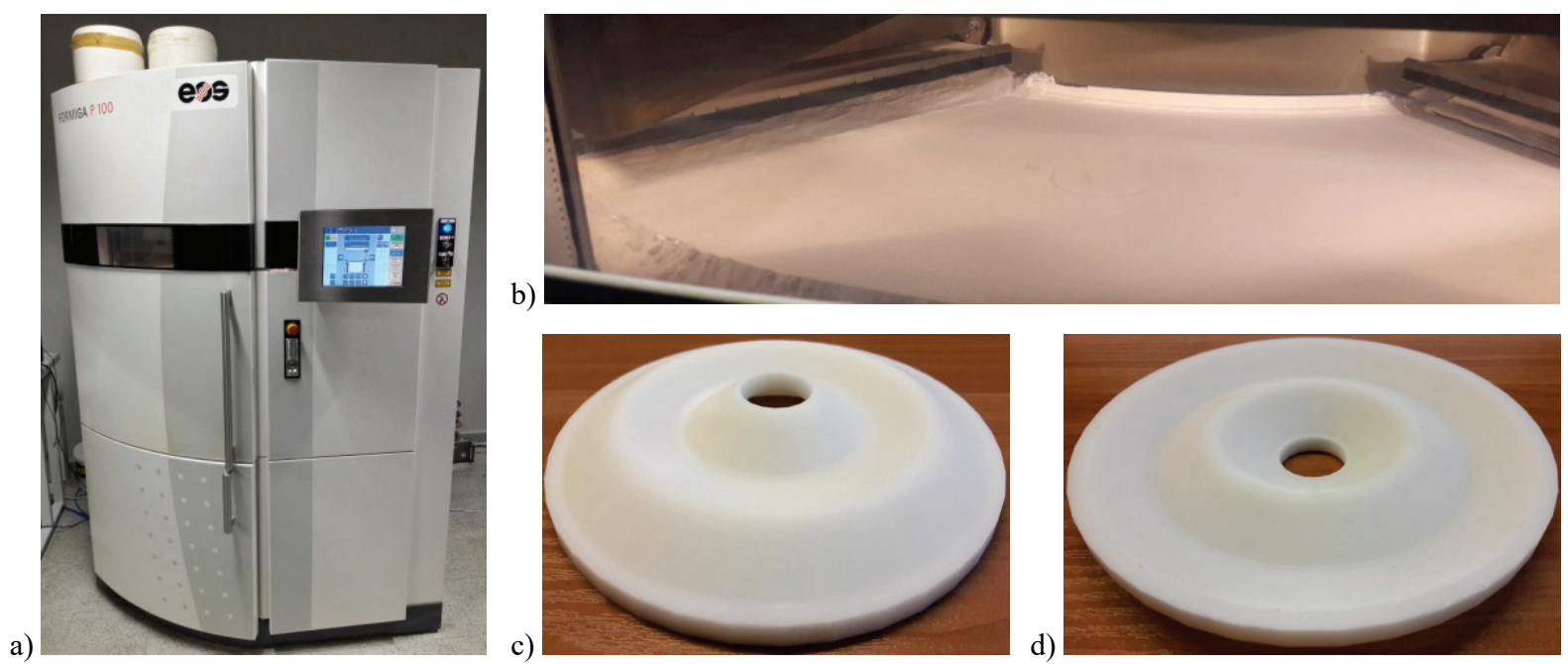

Fig. 6. 3D printing: a) Formiga P100 3D printer, EOS GmbH, b) production powder,

c) printed bearing plates (1st aerial view), d) printed bearing plates (2nd aerial view) (photo by K. Skrzypkowski)

gramming with the use of $\mathrm{CNC}$ machines. Based on the dimensions of circular bearing shaped plates, commonly used in the underground mining of copper ore in the region of LGOM, the prototype bearing plates were designed (Fig. 6c). After design preparation, the bearing plates were printed at the Faculty of Mechanical Engineering and Robotics in the Department of Manufacturing Systems using Formiga P100 3D printer, made by EOS GmbH (Fig. 6). The material used at this stage was Precymit which is the Chinese equivalent of Polyamide (PA2200) (Fig. 6b). The applied printing technology was SLS (Selective Laser Sintering), which aside from stereolithography (SLA), is one of the oldest methods of rapid prototyping and has been developed for more than 30 years. It is now one of the most widely used technologies in the short series production of technical final parts among all 3D printing methods. A growing number of companies use SLS as an alternative to the production of small mass, geometrically complicated parts made of polyamide. The major advantages of the SLS technology include:

a) high mechanical strength compared to other rapid prototyping technologies (approx. 80-90\% of the strength of a polyamide PA12 injection),

b) relatively low material and operation cost compared to other 3D printing technologies,

c) freedom of design due to no need for support structures,

d) easy cleaning of not sintered powder,

e) reusability of unsintered powder,

f) high-speed operation in the construction of a large number of parts compared to other $3 \mathrm{D}$ printing technologies.

This technology involves applying a layer of plastic powder in the working chamber whose bottom decreases with each layer by the value of its thickness. Then the laser beam selectively sinters the powder applied in the correct position. Next the work table is lowered and the arm provided with a roller or a blade applies the next powder layer. The process is repeated until printing is completed. The entire process takes place in a nitrogen atmosphere so as not to degrade or burn the material. In order to prevent the printed elements from deformation, the working chamber is heated to temperatures close to the melting point of the used material (approx. $170{ }^{\circ} \mathrm{C}$ ). For the same reason, immediately after printing the newly made elements should cool slowly in the machine, the cooling time is equal to the printing time.

\section{LABORATORY TESTS OF THE LONG EXPANSION ROCK BOLT SUPPORT}

The statical test of the expansion connected long rock bolt support, was carried out on a laboratory test facility (Fig. 7) in the Department of Underground Mining at Faculty of Mining and Geoengineering. The test facility simulated mine conditions, in particular the conditions typical of KGHM Polish Copper S.A. The aim of the research was to obtain the stress-strain characteristics of the long expansion connected rock bolt with a steel bearing plate printed on a $3 \mathrm{D}$ printer. In the statical mode, the power was gradually increased. The increase in the load of the tested bolt and the hold time were implemented using a pressure regulator until the bolt broke. Because the rod bolts 


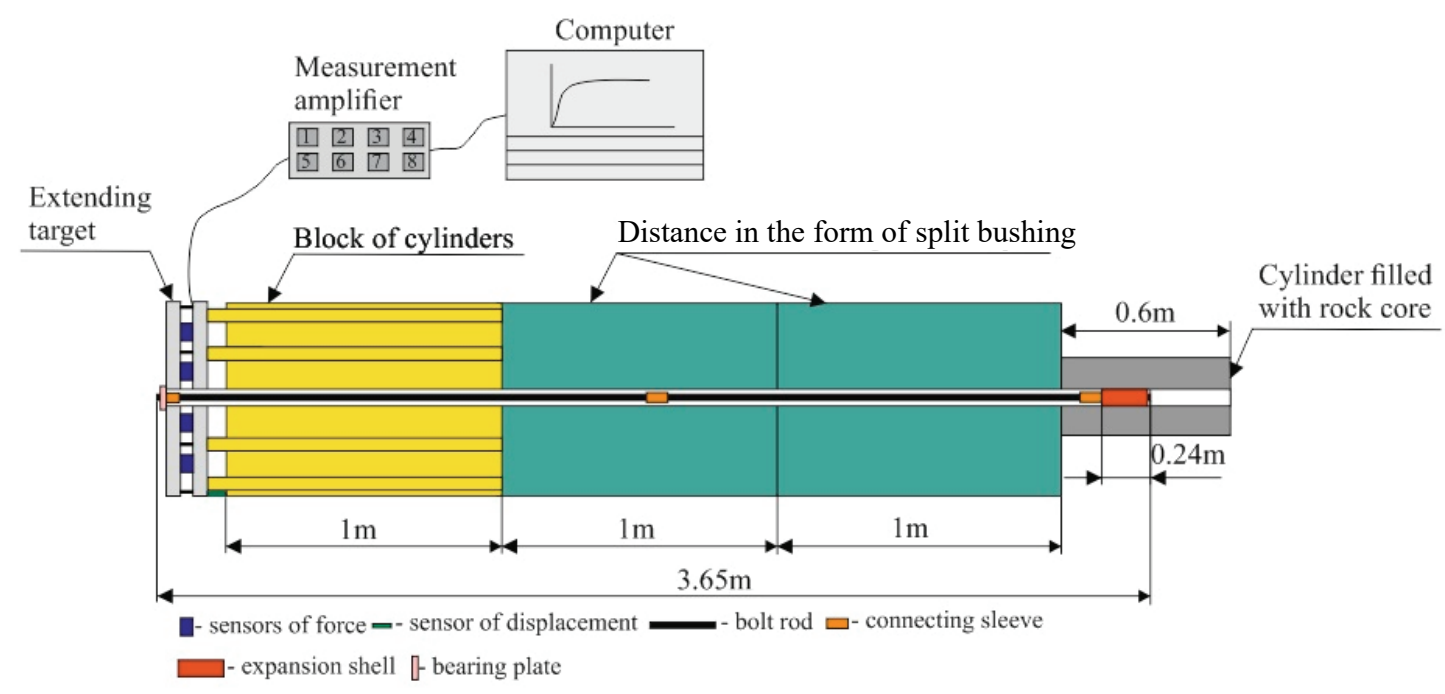

Fig. 7. Block diagram of the hydraulic power supply system of the long expansion rock bolt

used in the research were long, an additional split bushing cylinder and a cylinder filled with core rock, obtained from the roof of the room excavation in the Polkowice-Sieroszowice mine, were placed behind the block on the support frame. Force measurement on the laboratory test facility was performed using four strain gauge force sensors. The total force recorded during the tensile tests of the rod bolt was the sum of the forces generated on individual sensors. In the research KKM 50 sensors were used. The displacement measurement of support elements and the extension measurements of the anchor rod were carried out using a HLS-S-10-01 rope incremental encoder. The force and displacement sensors were connected to a MX840 QuantumX universal measuring amplifier. During the tensile strength measurements, the force and displacement results were recorded continuously using the CatMan - EASY software [22]. The program enables the ongoing (on-line) visualization and evaluation of the measurement. The used power supply system was a hydraulic power supply unit built based on an axial piston pump with variable speed regulators with constant power and constant pressure. The maximum supply pressure was $31 \mathrm{MPa}$.

In order to make sure that the laboratory tests conditions correspond best with the mine conditions, a steel cylinder with an external diameter of $102 \mathrm{~mm}$ and a length of $600 \mathrm{~mm}$, filled with a rock core (dolomite) from the roof voids, was used on the facility (Fig. 8). Dolomite is characterized by a compressive strength of at least $100 \mathrm{MPa}$. The core had a diameter of $90 \mathrm{~mm}$ and was inserted into the pipe using polyester resin. A hole, $26 \mathrm{~mm}$ diameter, was drilled in the core for an expansion head, $25 \mathrm{~mm}$ diameter. The radially arranged holes had the same diameter as the holes made in the roof of exploitation rooms.

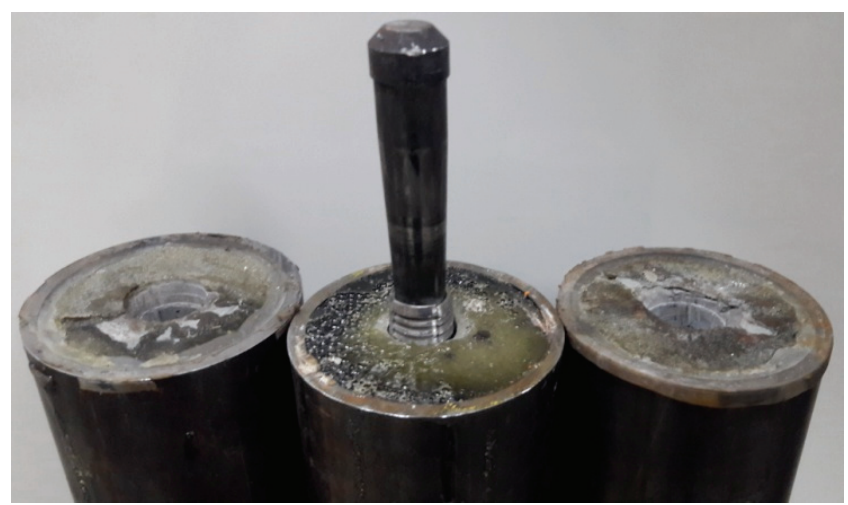

Fig. 8. Cylinders filled with rock cores (photo by K. Skrzypkowski)

\subsection{DESCRIPTION OF THE LONG EXPANSION ROCK BOLT SUPPORT}

The laboratory tests were carried out according to a uniform methodology for the long bolt support with a steel bearing plate and a bearing plate printed on a 3D printer. Two settings were used for the prototype bearing plates; the correct one, when the contact surface with the boundary plane is the greatest (Fig. 9a, $9 \mathrm{c})$ and the incorrect setting when there is no complete contact with the boundary plane (Fig. 9b, 9d). The prototype profiled bearing plates had a diameter of $136 \mathrm{~mm}$ and a thickness of $6 \mathrm{~mm}$. The support used in the tests was a long connected expansion rock bolt support with a total length of $3.65 \mathrm{~m}$, which is an additional support in excavations and is more and more 
a)

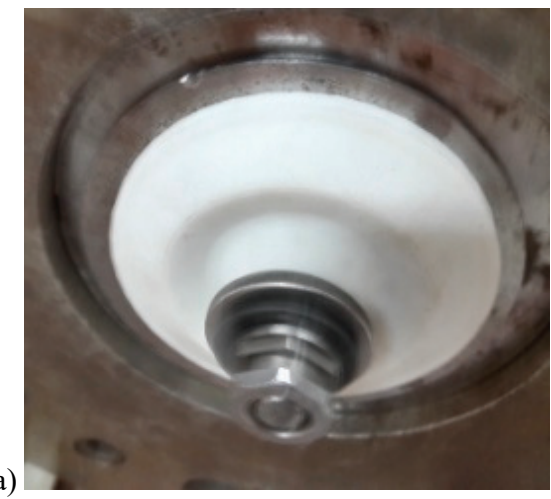

c)

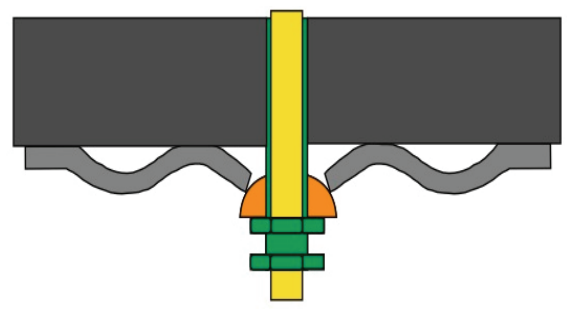

b)

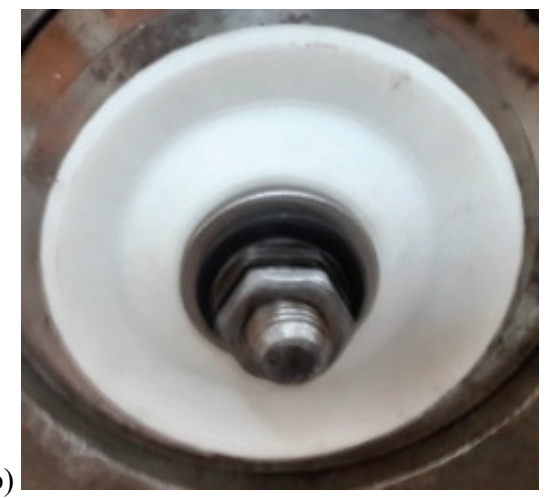

d)

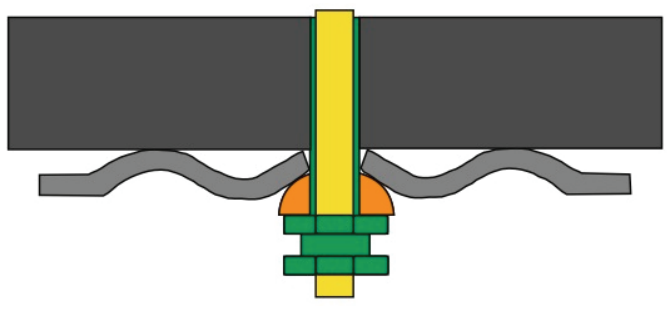

Fig. 9. Settings of the prototype bearing plates: a) correct - general view, b) incorrect - general view, c) correct setting, d) incorrect setting (photo by K. Skrzypkowski)

a)

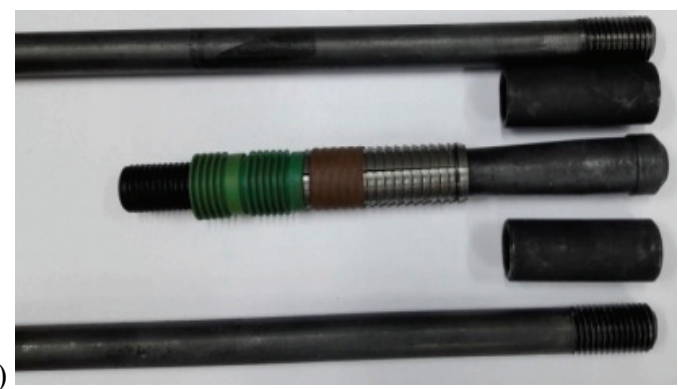

b)

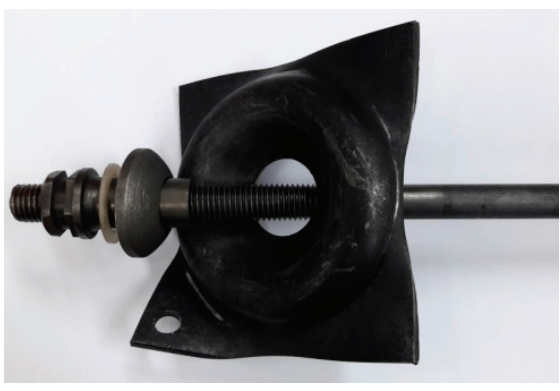

Fig. 10. Elements of expansion long rock bolt OB25: a) expansion shell, bolt rods and connecting sleeves, b) bearing plate with a sleeve nut, dome plate, gasket and smooth rod (photo by K. Skrzypkowski)

frequently used to reinforce the roofs and also to reconstruct underground mines, KGHM Polish Copper S.A. The rod bolts were made of steel grade OB640 - factory norm (OBUDOWA Sp. z o.o., 2016). The OB25 bolt consists of an expansion head with a diameter of $25 \mathrm{~mm}$, two smooth steel rods with a diameter of $18.30 \mathrm{~mm}$ (the length of the rods was $1.7 \mathrm{~m}$ and they had thread endings (M20)), two joining sleeves having a diameter of $25.3 \mathrm{~mm}$ and a height of $65 \mathrm{~mm}$ (Fig. 10a), shaped bearing plate - side length $145 \div 155 \mathrm{~mm}$ and thickness $6 \mathrm{~mm}$, ball pad with a diameter of $55 \mathrm{~mm}$, sleeve nut with a height of $65 \mathrm{~mm}$ and hexagonal head (M20) and a gasket (Fig. 10b). The expansion head, $240 \mathrm{~mm}$ long, was made of an expander (a rod whose one side is provided with a common threaded end and the other one is a conical component, $103 \mathrm{~mm}$ long, which has a resistive plug ending, $14 \mathrm{~mm}$ long), two plastic hold sleeves and an expansion sleeve, which contains four jaws with a length of $75 \mathrm{~mm}$, attached to the expander (rod) using a round and a flat puller.

\subsection{STRESS-STRAIN CHARACTERISTICS OF EXPANSION ROCK BOLT SUPPORT}

Rod bolts were connected and introduced manually to a steel cylinder through a shield, a measuring hole in the hydraulic load of bolts and split bushing cylinders which provided the distance. The steel cylinder with the core of rock was located at the end of the split bushing cylinders. Then the bolt in the hole was installed using a torque wrench with a torque of $300 \mathrm{Nm}$, which corresponds to the pre-tensioning force of $58 \div 61 \mathrm{kN}$. One strutting point was the head 


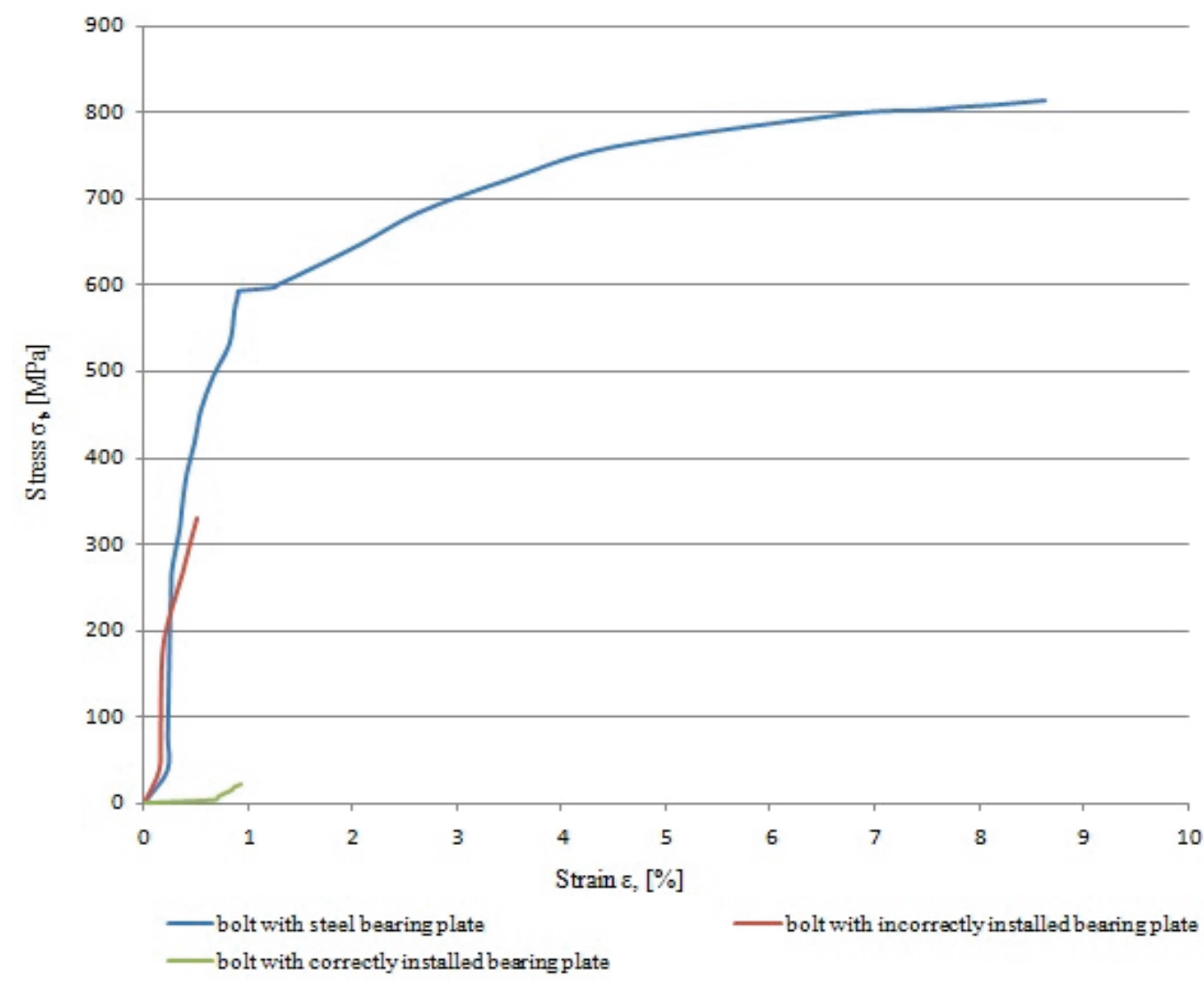

Fig. 11. Stress-strain characteristic of a long expansion rock bolt support with different bearing plates

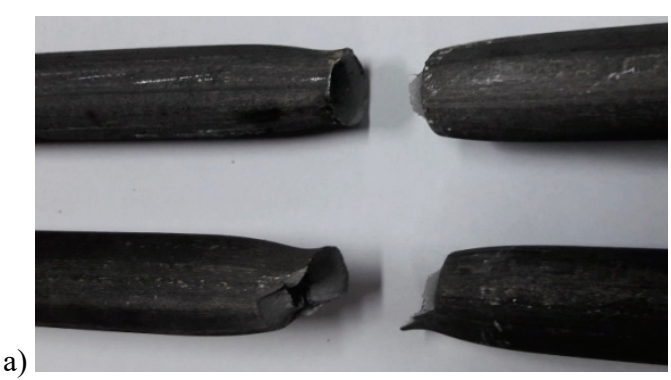

Fig. 12. Destruction of the studied materials: a) break on the bolt rod, b) destruction of the plastic bearing plate (photo by K. Skrzypkowski) installed in the core of the rock, while the other point was a sleeve nut, preceded by a gasket, a ball washer and a profiled bearing plate, resting on the extending target of the hydraulic equipment for loading bolts. The statical tensile tests of the bolt support consisted of a temporary increase in pressure by $10 \mathrm{bar}$, which were carried out by turning the reduction valve located on the control panel. Any increase in pressure was preceded by the hold time, which was 20 seconds. An example of tensile stress-strain characteristics is shown in Fig. 11. The failure of the tested material is presented in Figs. 12a and 12b.

The maximal load value for the long expansion connected bolt support was $214 \mathrm{kN}$, with maximum displacement equal to $310.99 \mathrm{~mm}$. The elastic range showed the value of $156 \mathrm{kN}$ corresponding to the displacement equal to $32.6 \mathrm{~mm}$. It is worth noting that when the initial tension was equal to $61 \mathrm{kN}$, displacements were at the level of $9 \mathrm{~mm}$. Under the influence of the maximal load, the material was broken on the 
smooth part of the rod bolt. At the narrowing part the diameter was $12.20 \mathrm{~mm}$, which means the reduction of the diameter by $6.1 \mathrm{~mm}$ with reference to the nominal diameter (Fig. 12). For the bolt support with the correctly set prototype bearing plate, only the residual characteristic was obtained, because at the load of only $6 \mathrm{kN}$ the dynamic breaking of the bearing plate took place (Fig. 12b). Slightly better stress-strain characteristic was obtained for the incorrectly built prototype bearing plate. The maximal load taken by the bolt amounted to $87.69 \mathrm{kN}$ (Fig. 11). The value of the transferred load is not sufficient for the conditions of the LGOM underground copper mines. The minimal carrying capacity of an expansion bolt support is $100 \mathrm{kN}$ (Polish Standard PN-G-15091). The bearing plate installed incorrectly took ten times more load than the bearing plate which was installed correctly. In the incorrect position the concave part of the bearing plate directly adjoins the sleeve nut part while the correct position does not provide such contact and this causes the accumulation of stresses.

Figure 11 shows maximal tensile stress $\sigma_{t \text { max }}$ calculated as the ratio of maximal breaking force $F_{\max }$ and its impact on the cross-sectional area of smooth rod bolt $d$ :

$$
\sigma_{t \max }=\frac{F_{\max }}{\frac{\pi \cdot d^{2}}{4}}, \quad \mathrm{MPa}
$$

The relative strain of bolt $\varepsilon$ is the value of the quotient of the total displacement (breaking elongation) of rod bolt $\Delta l$ by the active length of rock bolt $l_{0}$. The relative strain is the sum of the deformation of the rod in the cylindrical part and on the thread:

$$
\varepsilon=\frac{\Delta l}{l_{0}} \cdot 100, \quad \%
$$

The maximal value of the tensile stress for the long expansion connected bolt support was $813 \mathrm{MPa}$, at the maximal relative strain of the bolt equal to $8.64 \%$. The elastic range was $593 \mathrm{MPa}$ which corresponded with the relative strain of the bolt equal to $0.9 \%$. For the initial tension equal to $237 \mathrm{MPa}$, the relative strain was at the level of $0.25 \%$. For the bolt support with the correctly constructed prototype bearing plate only the residual characteristic was obtained, because at the tensile stress of only $22.8 \mathrm{MPa}$ the dynamic breaking of the bearing plate took place. Slightly better stressstrain characteristics were obtained for the incorrectly built in prototype bearing plate. The maximum tensile stress which was taken by the bolt reached $330.77 \mathrm{MPa}$, which corresponds to the maximal relative strain equal to $0.52 \%$ (Fig. 11).

\section{CONCLUSIONS}

The main function of every mining support is the protection of mining excavations from roof rock falls. The diversity of the lithological types of roof rock within the preparatory and exploitation excavations results in the fact that some roofs tend to fall in a very short period of time after they are uncovered. The use of rock bolt supports for the reconstruction of excavations in the period from 2010 to 2015 in the "Polkowice-Sieroszowice" copper mine, was in the range of $5.11 \%$ to $8.41 \%$ with an upward trend. The presented data indicate that in the coming years there will be no significant improvement in these statistics, or even that the problem will grow as a result of the deterioration of roof conditions, in particular excavation areas. In difficult geological and mining conditions new technological solutions for the bolt support will be used more and more often, they will encompass, e.g., modern construction materials, new types of resins for bonded bolts, various geometries of heads, rods and bearing plates in expansion bolts. A significant role in the reconstruction of excavations will be played by the long fixing bolts, suspending and strengthening larger packages of roof layers. The growth in the number of bolt supports used in underground copper mines is influenced not only by the increasing number of reconstructions, but also by the larger and larger area of uncovered roofs. However, this increase is not proportional, for instance in the years 2012 and 2013 there was a slight reduction in the exposed surface and in the years 2014 and 2015 there was a significant increase. The difference between 2015 and 2010 is $91286 \mathrm{~m}^{2}$. This is mainly the consequence of the decreasing thickness of copper deposits and copper content in the ore. This results in the need for increased production, and consequently larger exposed surfaces to achieve the intended results in copper production.

The primary measure of the corrosion process, which allows to visually assess the corrosion of a support, is the corrosion of bearing plates, rod bolt ends and nuts as they are constant contact with mine atmosphere. The effect of corrosion is the destruction of particular bolt elements causing the deterioration of cooperation between rock mass and bolts or even its complete destruction. Effective protection, i.e., involving the selection of materials, construction type 
and corrosion protection fit for the specific conditions of the mine corrosive environment, is desirable for reasons related to safety and costs associated with excavation maintenance. In the laboratory research a prototype bearing plate was used. It was printed on the 3D printer Formiga P100 from EOS GmbH using "Precymit" as the material, a white powder based on polyamide 12 which is a versatile material. After research it was found out that the used material did not meet the requirements of the expansion capacity for a bolt support for underground copper mining. "Precymit" is a cheaper equivalent of Polyamide (PA2200). It is characterized by lower strength and stiffness compared to PA2200. Both powder materials have good chemical resistance and low weight compared to steel bearing plates. Undoubtedly, the cost of a printing material cannot compete with conventional steel grades.

In underground mining excavations of the Legnica -Głogów Copper District, cement cable bolts with a length of $5 \mathrm{~m}$ and $7 \mathrm{~m}$ are commonly used, around 11 thousand units per year per one mining plant. Today, long expansion connected bolt supports with a length of $3.5 \mathrm{~m}$ and $5.2 \mathrm{~m}$ are more and more often used to strengthen the roofs and also in reconstructions. A characteristic feature of the bolt is its ability to connect steel rods of any length, typically $1.7 \mathrm{~m}$ joined with connecting sleeves. This type of supports can be installed during the same process as short rock bolt supports (up to $2.6 \mathrm{~m}$ ). The main advantage of the long expansion bolt support, OB25 type, is its building time. The comparison of the building times of expansion bolts with cement grouted cable bolts shows that in the case of the expansion bolts the complete building time takes no more than 10 minutes, while for the cement grouted cable bolts the same process can be completed in a day. This is related primarily to the setting time of cement mortar. In underground copper mining in Poland, it is required that the minimum force taken by the bearing plate must be at least $80 \mathrm{kN}$ at continuous fixing and it should be equal to the capacity of the rock bolt at the sectional fixing. The bolts selected for the laboratory tests were rock bolts with commonly used round shape bearing plates. The material used to print the prototype bearing plates did not meet the requirements of taking over the capacity of rock bolts at a sectional fixing. Spatial printing of commonly used bearing plates of 6 , $8,10 \mathrm{~mm}$ thickness and different shapes requires additional testing in numerical programs.

The laboratory research was conducted on a modern test facility in the Department of Underground Mining AGH, which enabled testing rock bolt sup- ports on a scale of 1:1. The maximum rod length was $6 \mathrm{~m}$. Based on the laboratory tests it can be stated that the maximal tensile stress for the long expansion connected bolt support was $813 \mathrm{MPa}$, at the maximum relative strain equal to $8.64 \%$. The bolt took over the breaking load of $214 \mathrm{kN}$ equal to the maximum displacement of $310.99 \mathrm{~mm}$. It is worth noting that the smooth rod bolts, $18.30 \mathrm{~mm}$ diameter, made of steel grade OB640 showed more than 100\% load capacity required in the mining regulations related to the expansion bolts in underground copper mining. Another advantage of the tested support was its high relative strain, which in the case of energy absorption is a very desirable feature.

\section{ACKNOWLEDGEMENTS}

This study was developed as part of the statutory work No. 11.11.100.005.

\section{REFERENCES}

[1] Biliński J., Kosior A., Malik D., RzePeCKi W., Niektóre zagadnienia związane z korozja obudowy kotwiowej zabezpieczajacej wyrobiska drążone $w$ II $i$ III stopniu zagrożenia wodnego w ZG „POLKOWICE”. Materiały konferencyjne „Obudowa kotwiowa jako skuteczny sposób zabezpieczenia wyrobisk w kopalniach rud miedzi”, Lubiatów 1996, Wydawnictwo Centrum Badawczo-Projektowe Miedzi „Cuprum” Sp. z o.o. Wrocław, 119-125.

[2] Burtan Z., Zorychta A., CieŚlik J., Chlebowski D., Influence of mining operating conditions on fault behavior, Archives of Mining Science, 2014, 59(3), 691-704.

[3] Heming W., Xuefeng Z., Dongsheng L., Pinglei Z., ChANGSEn S., Corrosion monitoring of rock bolt by using a low coherent fiber-optic interferometry, Optics \& Laser Technology, 2015, 67, 137-142.

[4] http://www.nitrex.com

[5] KORZENIOWSKI W., Ocena stanu podziemnych wyrobisk chodnikowych i komorowych na podstawie empirycznych metod badawczych. Rozprawy - Monografie, nr 156, Uczelnianie Wydawnictwa Naukowo-Dydaktyczne AGH, Kraków 2006.

[6] Korzeniowski W., HerEzy Ł., SKRZYPKOWSKI K., Korozja stalowej obudowy EP wyrobiska chodnikowego w środowisku kopalni soli, Rudy i Metale Nieżelazne Recykling, 2015, 9, 405-413.

[7] KorZENIOWSKI W., SKrzypKowsKi K., Herezy Ł., Laboratory method for evaluating the characteristics of expansion rock bolts subjected to axial tension, Archives of Mining Science, 2015, 60(1), 209-224.

[8] KorzenIOWSKI W., SKrZYPKOWSKi K., Metody badania górotworu kotwami przy obciązeniach dynamicznych, Przegląd Górniczy, 2011, 3-4,1-8.

[9] Korzeniowski W., SkrzypKowski K., Zagórski K., Reinforcement of Underground Excavation with Expansion Shell Rock Bolt Equipped with Deformable Component, Studia Geotechnica et Mechanica, 2017, 1 (article in progress).

[10] Li C.C., A new energy - absorbing bolt for rock support in high stress rock masses, International Journal of Rock Mechanics and Mining Science, 2010, 47(3), 396-404. 
[11] MaŁKOwKi P., StęPIEŃ A., Wspótpraca kotwi z górotworem, Bezpieczeństwo Pracy i Ochrona Środowiska w Górnictwie, 2015, 11, 24-33.

[12] MoOSAV M., Karimi S., Corrosion protection of rock bolts by epoxy coating and its effect on reducing bond capacity, AZIZ N (ed.) Coal Operators' Conference, Coal 2008, University of Wollongong \& the Australasian Institute of Mining and Metallurgy, 2008, 117-124.

[13] NiEROBISZ A., The model of dynamic loading of rockbolts, Archives of Mining Science, 2006, 51(3), 453-470.

[14] OBUDOWA Sp. z o.o., 2016 - Dokumentacja techniczna łączonych kotwi rozprężnych typu OB25. KHGM Polska Miedź S.A.

[15] Piechota S., Stopyra M., Stasica J., Wpływ konstrukcji żerdzi kotwi wklejanej na efektywność jej utwierdzenia, Przegląd Górniczy, 2002, 7-8, 35-41.

[16] POLSKA NORMA PN-G-015091: Kotwie górnicze - Wymagania.

[17] Prusek S., Rotkegel M., MaŁecki Ł., Wybrane sposoby wzmacniania skorodowanej stalowej obudowy odrzwiowej, Przegląd Górniczy, 2015, 5, 71-77.

[18] Pytel W., Geomechaniczne problemy doboru obudowy kotwowej dla warunków wyrobisk górniczych, Wydawnictwo KGHM CUPRUM Sp. z o.o. Centrum Badawczo-Rozwojowe, Wrocław 2012.

[19] Pytlik A., Prusek A., Masny W., A methodology for laboratory testing of rockbolts used in underground mines under dynamic loading conditions, SAIMM Journal of the Southern African Institute of Mining and Metallurgy, 2016, $12,1101-1110$.

[20] Rogoż M., Hydrogeologia kopalniana z podstawami hydrogeologii ogólnej, Główny Instytut Górnictwa, Katowice 2004.

[21] RuseK P., Wantuch E., ZAGÓRSKI K., The problem of energy-consuming processes in the planning of modern manufacturing Technologies, Journal of Machine Engineering, 2013, Vol. 13, No. 4, 68-76.

[22] SkrzypKowski K., KorZENIOwski W., Herezy Ł., Metody badania obudowy kotwowej w Katedrze Górnictwa Podziemnego AGH, Cuprum, 2015, 3, 49-60.

[23] SKRZYPKOwSKI K., ZAGÓRSKI K., DUdEK P., Zastosowanie drukarki $3 D$ do produkcji prototypowej podkładki kotwowej, Przegląd Górniczy, 2016, 3, 52-56.

[24] SKRZYPKOwSKI K., Zastosowanie obudowy kotwowej podatnej celem poprawy stateczności wyrobisk poprzez częściowe przejmowanie deformacji górotworu, Przegląd Górniczy, 2012, $4,1-11$.

[25] Śledź T., Ratajczak A., GŁuch P., Problemy korozji kotwi strunowych $w$ podziemnych wyrobiskach górniczych, Materiały konferencyjne XXIV Szkoły Eksploatacji Podziemnej, Kraków 2015, 1-10.

[26] Tajduś A., CaŁa M., TAJduś K., Geomechanika w budownictwie podziemnym: projektowanie i budowa tuneli, Wydawnictwa AGH, Kraków 2012. 